Results: Over a 2-month period (April-May 2014), there were 248 (25\%) RA attendees of 1000 participants. Significant differences were observed between current, past and non-smokers in regard to age [mean (SD): 59.5 (10.0) vs. 65.2 (10.6) vs. 61.0 (18.2) years; $p=0.034$ ], gender (male: $23.9 \%$ vs. $30.3 \%$ vs. $14.6 \%$; $p=0.027$ ), unemployment due to disability ( $13.3 \%$ vs. $3.1 \%$ vs. $4.9 \% ; p=0.044)$, number of RA medications [mean (SD): 2.3 (1.1) vs. 2.1 (1.1) vs. 1.8 (1.1); $\mathrm{p}=0.019$ ], DMARD use $(78.3 \%$ vs. $82.8 \%$ vs. $64.1 \% ; \mathrm{p}=0.008)$, opioid use $(19.6 \%$ vs. $10.1 \%$ vs. $3.9 \%$; $p=0.009$ ), pain [mean (SD): 5.0 (3.3) vs. 4.0 (2.9) vs. $3.7(2.6)$ $\mathrm{cm} ; \mathrm{p}=0.040$ ] and PGA [mean (SD): 3.8 (2.8) vs. 3.1 (2.8) vs. $3.0(2.4) ; p=0.039$ ]. Recreational marijuana was used by 3 non cigarette smokers only, with 1 also reporting medicinal marijuana use. Ever smokers vs. non-smokers used a greater number of RA medications [mean (SD): 4.3 (3.0) vs. 3.7 (2.6); $p=0.081$ ], were more likely to use DMARDs ( $81.4 \%$ vs. $64.1 \% ; \mathrm{p}=0.003)$ and opioids $(13.1 \%$ vs. $3.9 \% ; p=0.014)$, and showed a trend towards more pain [mean (SD): $4.3(3.0)$ vs. 3.7 (2.6); $p=0.081]$. In multivariate analysis, male gender $(\mathrm{OR}=2.193 ; \mathrm{p}=0.025)$ and DMARD use $(\mathrm{OR}=2.376 ; \mathrm{p}=0.010)$ were significantly associated with ever smoking while opioid use $(\mathrm{OR}=2.784, \mathrm{p}=0.103$ for ever smoking; $\mathrm{OR}=3.561$, $\mathrm{p}=0.074$ for current smoking) showed a statistical trend.

Conclusions: Current, but also ever cigarette use, was associated with worse RA disease as indicated by the use of more drug categories, and more likely use of DMARDs to treat RA, and a trend to more pain and opioids. The combination of opioids and cigarettes may be a manifestation of a patient "chemical coping" strategy in RA patients.

Disclosure of Interest: None declared

DOI: 10.1136/annrheumdis-2017-eular.3777

\section{FRI0116 A HIGH LEVEL OF CLINICAL RESPONSE BASED ON COMPOSITE INDICES IS ASSOCIATED WITH IMPROVED HEALTH-RELATED QUALITY OF LIFE: ANALYSES FROM A PHASE 3 CLINICAL TRIAL IN PATIENTS WITH RHEUMATOID ARTHRITIS}

M. Dougados ${ }^{1}$, B. Zhu ${ }^{2}$, A.C. Tang $^{2}$, A. Quebe ${ }^{2}$, I. Stoykov ${ }^{2}$, Z. Cai ${ }^{2}$, M. Ishida ${ }^{2}$, C. Gaich ${ }^{2}{ }^{1}$ Hopital Cochin, Paris, France; ${ }^{2}$ Eli Lilly and Company, Indianapolis, United States

Background: Rheumatoid arthritis (RA) is a chronic disease associated with inflammatory activity and joint damage that result in disability, pain, and other impairments. The current recommendation is to assess disease activity based on composite indices with objective signs of inflammation (e.g. synovitis, acute phase reactants) and patient's assessment of disease activity. The patient's perception of disease impact and its treatment also facilitate shared decision-making about treatment.

Objectives: To compare patient-reported outcomes (PROs) for RA patients who achieved low disease activity (LDA) or remission based upon the DAS28-ESR compared to those with moderate and high disease activity (MDA and HDA) in this post-hoc analysis of a randomized, double-blind phase 3 clinical trial, RA-BEAM ${ }^{1}$. Methods: 1305 patients were randomized to placebo $(\mathrm{N}=488)$, adalimumab $(\mathrm{N}=330)$ or baricitinib $4 \mathrm{mg}(\mathrm{N}=487)$. Patients with observed DAS28-ESR values at Week $24(\mathrm{~N}=1,010)$ were divided into 4 disease activity groups: HDA (DAS28-ESR $>5.1)$, MDA (3.2<DAS28-ESR $\leq 5.1)$, LDA $(2.6 \leq \mathrm{DAS} 28-\mathrm{ESR} \leq 3.2)$, or remission (DAS28-ESR<2.6). Change from baseline to Week 24 were assessed for the pain visual analogue scale (VAS, 0-100 mm), Health Assessment Questionnaire-Disability Index (HAQ-DI) and SF-36 physical and mental component score (PCS and MCS) for the intent-to-treat (ITT) patients.

Results: Patients with HDA and MDA at Week 24 had greater baseline pain and HAQ-DI scores and lower PCS and MCS scores than patients achieving LDA or remission at Week 24. Lower disease activity at Week 24 was associated with improvement in pain, HAQ-DI, SF-36 PCS and MCS at Week 24. Among patients who achieved remission, residual pain was observed, with close to $40 \%$ still experiencing some level of pain and $20 \%$ of patients in remission at Week 24

Table 1. Improvement in disease activity is associated with improved PROs.

\begin{tabular}{|c|c|c|c|c|c|}
\hline \multirow{2}{*}{$\begin{array}{c}\text { PRO } \\
\text { Measures }\end{array}$} & \multirow{2}{*}{$\begin{array}{l}\text { Outcomes } \\
\text { at Week } \\
24\end{array}$} & \multicolumn{4}{|c|}{ Disease Activity at Week 24} \\
\hline & & $\begin{array}{c}\text { HDA } \\
\text { DAS28-ESR }>5.1 \\
\text { N=210 }\end{array}$ & $\begin{array}{c}\text { MDA } \\
3.2<\text { DAS28-ESR } \leq 5.1 \\
N=490\end{array}$ & $\begin{array}{c}\text { LDA } \\
2.6 \leq D A-28-E S R \leq 3.2 \\
N=142\end{array}$ & $\begin{array}{c}\text { Remission } \\
\text { DAS28-ESR } 2.6 \\
\text { N=168 }\end{array}$ \\
\hline \multirow[t]{4}{*}{ Pain VAS } & Baseline & 65.8 & 61.3 & 56.6 & 51.9 \\
\hline & $\begin{array}{l}\text { LsM } \\
\text { Change }\end{array}$ & -10.6 & $-31.0^{\mathrm{a}}$ & $-43.2^{\mathrm{ab}}$ & $-46.7^{\mathrm{ab}}$ \\
\hline & $\begin{array}{l}\text { Pain } \\
\text { vaS } \leq 10, \\
\text { \% }\end{array}$ & 1.4 & $19.0^{\circ}$ & $48.6^{\mathrm{ab}}$ & $60.7^{\mathrm{ab}}$ \\
\hline & $\begin{array}{l}\text { Pain } \\
\text { vas } \leq 20, \\
\text { \% }\end{array}$ & 7.6 & $37.1^{\circ}$ & $70.4^{\mathrm{ab}}$ & $79.2^{\mathrm{ab}}$ \\
\hline \multirow[t]{2}{*}{ HAQ-DI } & Baseline & 1.8 & 1.6 & 1.4 & 1.2 \\
\hline & $\begin{array}{l}\text { LSM } \\
\text { Change }\end{array}$ & -0.3 & $-0.7^{\mathrm{a}}$ & $-1.0^{\mathrm{Ab}}$ & $-1.0^{\circ \mathrm{bb}}$ \\
\hline \multirow[t]{2}{*}{$\begin{array}{l}\text { SF-36 } \\
\text { PCS }\end{array}$} & Baseline & 29.7 & 32.1 & 34.3 & 37.2 \\
\hline & $\begin{array}{l}\text { LSM } \\
\text { Change }\end{array}$ & 3.3 & $8.0^{a}$ & $12.9^{\mathrm{ab}}$ & $13.6^{\mathrm{ab}}$ \\
\hline \multirow[t]{2}{*}{$\begin{array}{l}\text { SF-36 } \\
\text { MCS }\end{array}$} & Baseline & 44.3 & 46.2 & 46.7 & 49.8 \\
\hline & $\begin{array}{l}\text { LSM } \\
\text { Change }\end{array}$ & 1.8 & $4.1^{\circ}$ & $5.6^{\circ}$ & $5.2^{\circ}$ \\
\hline
\end{tabular}

had a residual pain score $>20$. Sensitivity analyses using other clinical measures (DAS28-CRP, SDAI, CDAI) to define disease activity confirmed the findings.

Conclusions: Improving patient disease activity is associated with improved health-related quality of life. Patients who achieved remission had greater improvement in PROs but residual pain remained. Further research is needed to understand the treatment differences in the association between disease activity and PROs among different therapies.

References:

[1] Taylor PC, Keystone E, van der Heijde D, et al. Baricitinib Versus Placebo or Adalimumab in Patients with Active Rheumatoid Arthritis (RA) and an Inadequate Response to Background Methotrexate Therapy: Results of a Phase 3 Study. Arthritis Rheum 2015;67(Suppl 10):3928.

Disclosure of Interest: M. Dougados Grant/research support from: Abbvie, Pfizer, Eli Lilly and Company, Novartis, UCB, Merck, Roche, BMS, Consultant for: Abbvie, Pfizer, Eli Lilly and Company, Novartis, UCB, Merck, Roche, BMS, B. Zhu Employee of: Eli Lilly and Company, A. Tang Employee of: Eli Lilly and Company, A. Quebe Employee of: Eli Lilly and Company, I. Stoykov Employee of: Eli Lilly and Company, Z. Cai Employee of: Eli Lilly and Company, M. Ishida Employee of: Eli Lilly and Company, C. Gaich Employee of: Eli Lilly and Company DOI: 10.1136/annrheumdis-2017-eular.1344

\section{FRI0117 CHRONOLOGICAL CHANGES IN ACHIEVING J-HAQ REMISSION IN PATIENTS WITH EARLY-STAGE RHEUMATOID ARTHRITIS IN THE IORRA COHORT}

M. Ochiai ${ }^{1}$, E. Tanaka ${ }^{1}$, E. Inoue ${ }^{1,2}$, R. Yamaguchi ${ }^{1}$, Y. Shimizu ${ }^{1}$,

N. Sugimoto ${ }^{1}$, K. Ikari $^{1}$, A. Nakajima ${ }^{1}$, A. Taniguchi ${ }^{1}$, H. Yamanaka ${ }^{1}$

${ }^{1}$ Rheumatology, Institute of Rheumatology Tokyo Women's Medical University;

${ }^{2}$ Center for Clinical Research for Development, National Center for Child Health and Development, Tokyo, Japan

Background: With the introduction of biologic disease-modifying antirheumatic drugs (DMARDs) and the increase in the approved maximum dose of methotrexate in our country, the treatment of rheumatoid arthritis (RA) has advanced dramatically in the past 2 decades. Consequently, many patients were able to achieve clinical remission and low radiographic progression rates ${ }^{1-3}$. In view of these dramatic changes in RA treatment, we investigated whether the Japanese version of the Health Assessment Questionnaire (J-HAQ) improved chronologically due to improved treatment over time.

Objectives: To investigate chronological changes in achieving J-HAQ remission and the factors related to J-HAQ remission in Japanese patients with an early stage of RA.

Methods: RA patients who enrolled in the IORRA cohort for the first time between 2000-2002 (Term 1), 2005-2007 (Term 2), and 2010-2012 (Term 3) and were within 2 years of disease onset were examined. For each patient in Term 3, one patient was extracted from Term 1 and Term 2 by matching the sex, age, and J-HAQ score. Among them, patients with J-HAQ $>0.5$ at study entry (baseline) were selected; the time to achieve J-HAQ remission $(\mathrm{J}-\mathrm{HAQ} \leqq 0.5)$ and the J-HAQ remission rate at 3 years were analyzed. Multivariate analysis was performed to assess factors related to achieving J-HAQ remission.

Results: In each term, 348 RA patients were extracted. At baseline, the average J-HAQ of all 1,044 patients was 0.52 . Baseline characteristics of 408 patients with baseline J-HAQ $>0.5$ were as follows: female, $89.0 \%$; mean age, 56.3 years; anti-cyclic citrullinated peptide (anti-CCP) antibody positivity, $78.0 \%$; mean Disease Activity Score with 28-joint count (DAS28), 4.37; and mean J-HAQ, 1.11. The mean time from baseline to achieving J-HAQ remission became significantly shorter chronologically (Term 1: 2.2 years; Term 2: 1.8 years; Term 3: 1.7 years; $\mathrm{p}<0.005$, Fig.1). J-HAQ remission rates significantly increased in both Term 2 $(55.2 \%)$ and Term $3(57.4 \%)$ compared with Term $1(37.5 \% ; p<0.005)$. The factors significantly related to achieving J-HAQ remission at 3 years were younger age (OR 1.02; 95\% Cl 1.00-1.04) and enrollment in Term 2 (OR 2.0; 95\% Cl 1.2-3.5) or Term 3 (OR 2.3; 95\% Cl 1.3-4.1) compared with enrollment in Term 1.

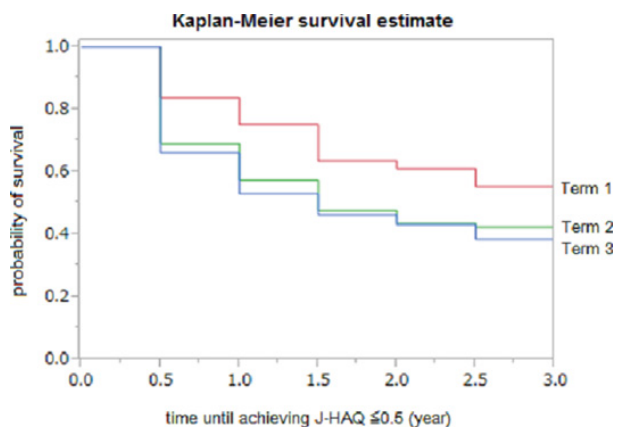

Conclusions: Along with the improvement in RA treatment, patients were able to achieve J-HAQ remission more frequently and more quickly.

References:

[1] Mod Rheumatol. 2007;17:283-9.2) J Rheumatol. 2015; 42:2279-87.3) Rheumatology. 2016;55:1053-1065. 